\title{
Implementation of Lean Six Sigma for Production Process Optimization in a Paper Production Company
}

\author{
Adefemi Adeodu ${ }^{1}$ iD, Mukondeleli Grace Kanakana-Katumba ${ }^{2}$ (D), Maladzhi Rendani ${ }^{1}$ iD \\ ${ }^{1}$ Department of Mechanical and Industrial Engineering, University of South Africa (South Africa) \\ ${ }^{2}$ Department of Industrial Engineering, Tshwane University of Technology, Pretoria (South Africa) \\ engrcharles520ca@gmail.com, KanakanaMG@tut.ac.za,maladrw@unisa.ac.za
}

Received: January 2021

Accepted: March 2021

\section{Abstract:}

Purpose: This study aims at implementing lean six sigma to evaluate the productivity and manufacturing wastes in the production line of a paper company

Methodology/Approach: The study is a case study in nature. The method illustrates how lean six sigma (LSS) is used to evaluate the existing production process in a paper production company with focus on productivity and manufacturing wastes. The study considered a real-time problem of customer's dissatisfaction. Gathered data were based on machine functionality (up time, down time and cycle time); materials and labour flow at every process stage of the production line. The optimization of the production process was based on lean tools like value stream mapping, process cycle efficiency, Kaizen, $5 \mathrm{~S}$ and pareto chart

Findings: Based on lean six sigma application, it was discovered that the present production performance was below standard and more manufacturing wastes were generated. The present productivity and manufacturing wastes are reported as low process cycle efficiency $(23.4 \%)$, low takt time $(4.11 \mathrm{sec})$, high lead time $(43200 \mathrm{sec})$, high number of products not conforming to six sigma values, high down time $(32.64 \%)$ and excess labour flow (33). After the implementation of the lean six sigma tools for certain periods, there were lots of improvements in the production lines in terms of all the parameters considered.

Research Limitations/ Implications: The study has demonstrated application of lean six sigma in the case of solving real-time problems of productivity and manufacturing wastes which have a direct implication on customer's satisfaction. The lesson learnt and implications presented can still be further modeled using some lean based software for validity

Originality/Value: The study has contributed to the body of knowledge in the field of LSS with focus to process-based manufacturing, unlike most literature in the field which concentrated more on discrete based manufacturing.

Keywords: lean manufacturing, lead time, process cycle efficiency, takt time, value added time

\section{To cite this article:}

Adeodu, A., Kanakana-Katumba, M.G., \& Rendani, M. (2021). Implementation of lean six sigma for production process optimization in a paper production company. Journal of Industrial Engineering and Management, 14(3), 661-680. https://doi.org/10.3926/jiem.3479 


\section{Introduction}

Lean popularly known as Lean Manufacturing is a set of principles embraced by industrial organizations in order to improve on production performance and customer's satisfaction at the same time eliminating wastes (Ahmed, Manaf \& Islam 2018; Mwacharo, 2013; Saidul Huq, 2018). It is a technique widely in use in manufacturing and supply chain management, but recently gaining implementation in other discrete industrial organizations (Mwacharo, 2013). Maintaining quality and reliable performance have become priority to production industries in order to gain customer satisfaction, as demand for the products increases (Gupta, Jain, Meena \& Dangayachi, 2018). Companies have to define, measure, analyze, make improvements and effect control on their existing manufacturing systems to comply with market competition (Gupta et al., 2018). Different methods, approaches and tools are being used for continuous productivity and quality improvements (Gupta et al., 2018). Aside these, each company or production sector is required to use a proper selection or combination of different approaches or tools in its implementation process (Sokovic, Pavletic \& Pipan, 2010). Down time and variations are inevitable in the course of production of any product, but the main goal of process management or process capability analysis in any organization is to investigate the causes of the down time during the production process of the product (Pearn \& Chen, 1999). This aids manufacturing organizations to monitor and measure the potential of process (Wu, Kuo $\&$ Chen, 2004).

Continuous improvement of process is a key concept of total quality management (Chen, Lu, Wang, Jang \& Dahlgaard, 2015), but other methodologies like re-engineering or automation, lean manufacturing will also give similar results of improved performance (Gupta et al., 2018).

Lean Manufacturing, a multidimensional production optimization approach that captures various management practices, aimed at wastes reduction and improving operational effectiveness (Roriz, Nunes \& Sousa, 2017). The evidence of implementation of the approach in the manufacturing sector is not limited to quality and productivity improvement, but also considers non-tangible change factors such as initiation of supportive learning environment and developing leadership in the organization (Gupta et al., 2018). To this effect, companies now trend strategy for continuous improvements on quality of their products/services to retain customers in order to gain market share (Chen et al., 2015). During the last economic crisis breakout of 2008, there was serious destabilization in the global market as both consumer demand and industrial production fell (Saidul Huq, 2018). Companies, most especially the process related were left with massive quantities of inventories that could not be disposed as a result of the intensity of receding sales (Beacham, 2018), which led to serious reduction in industrial production especially in EU and USA (Saidul Huq, 2018). Figure 1 shows the industrial production volume rates between 2005-2016.

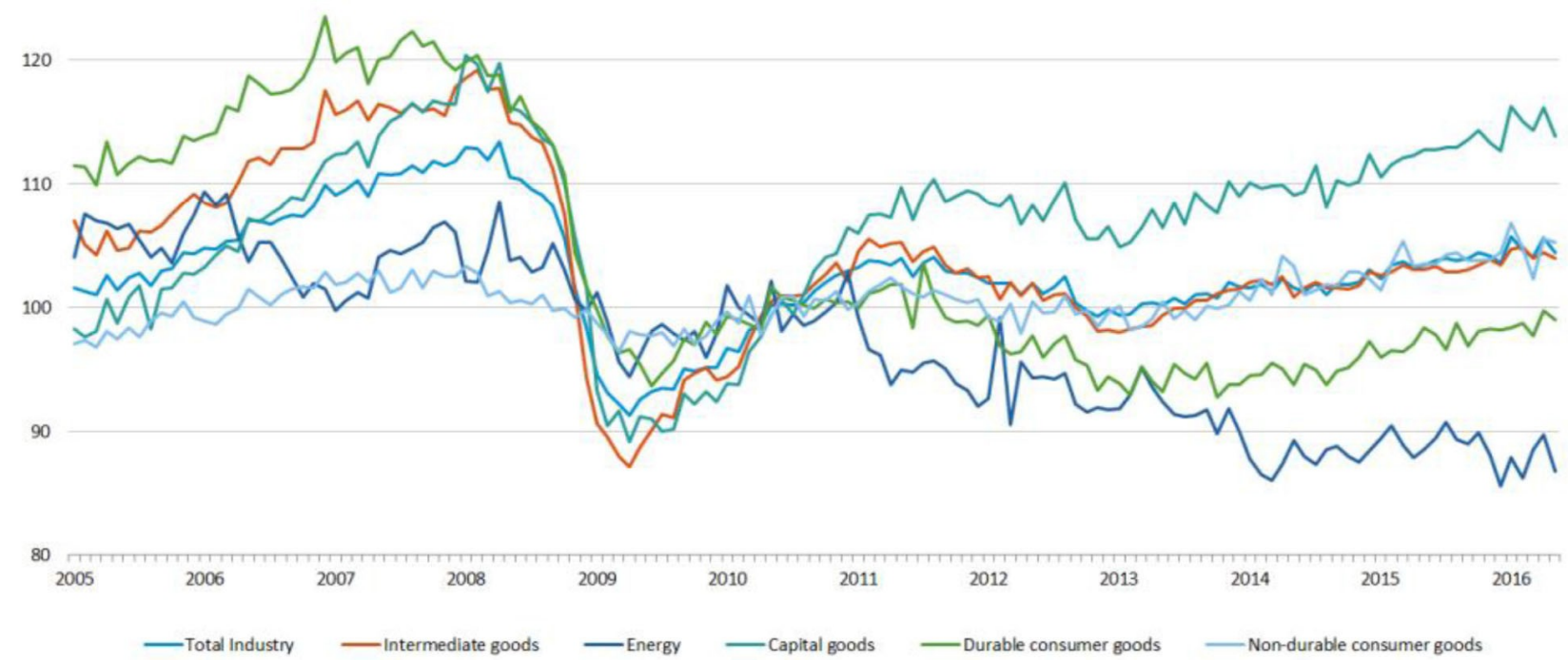

Figure 1. Industrial Production Volume rate between 2005-2016 (Eurosat, 2017) 
In the last two years, a gradual rising trend is seen Atradius Conduction Team (ACT) (2018). As a result of the crisis, industrial focus was geared toward cost reduction by some radical means such as facility shutdowns, mergers and even quality reduction (Saidul Huq, 2018), instead of refocusing on production re-engineering with tilt improvement of process and operational characteristics towards Lean mode of production (Saidul Huq, 2018), elimination of wastes and enforcing quality at all stages (Anthony, 2018). Also, before 1980s, process industries were seriously facing the challenge of low productivity as a result of poor work standardization (Sayidmia, 2016). It was discovered that majority of the existing processes of production contained some non-value adding activities which invariably led to prolonged production cycle (Sayidmia, 2016). By eliminating the non-value adding activities from the processes and streamlining the workflow towards the finished product, can significantly optimize productivity (Harrington, 1996; Moser, Isaksson \& Seifert, 2017). Due to globalization, customer satisfaction has become more prevalent to manufacturing companies, especially in the area of lead time which defines the time difference between the release of customer's order and delivery. Therefore, success and sustenance of businesses in the global market demand customer satisfaction in terms of short lead time and conformity in quality of products (Gaither, 1994; Moser et al., 2017). LSS model as proposed by Crawford (2004) has presented how Six Sigma can first be applied to improve the processes effectiveness followed by lean to improve the system efficiency. However, it is better to draw on both simultaneously to achieve the idea of integration. To succeed in integrating lean with Six Sigma, organizations need to adopt a holistic improvement method, where lean and Six Sigma mutually reinforce each other. An integrated approach is expected to include the use of a current state VSM as a platform for applying Six Sigma and lean tools, applying Six Sigma to adjust process parameters, integrating lean techniques into DMAIC and using future state VSM as a way to change the structure of the process. The integration of lean and Six Sigma is the solution to overcome the shortcomings of both, as they complete each other. The fusion of the two is the way for organizations to increase their potential improvements (Bhuiyan \& Baghel, 2005). The integration of Six Sigma and lean help companies achieve zero defects and fast delivery at low cost. A more detailed description of this integration is needed in order for organizations to succeed in exceeding future customer demands.

There are several works reported on the use of lean six sigma by different authors which are not limited to manufacturing sector. In the study of Madsen, Risvik and Stenheim (2017), lean was implemented in the public sector of Norwegian municipality as a management tool for improving productivity and performance. Chiarini (2012) reported the use of lean six sigma as a tool for risk management and cost reduction of cancer drugs in health services. Furterer and Elshennawy (2011) also implemented lean six sigma in similar health sector to reduce linen loss in an acute care hospital. The use of lean six sigma in in-service sector for the improvement of productivity and performance were reported by Bazrkar, Iranzadeh and Farahmand (2017); Edgeman (2010); Laureni and Antony (2010); Meza and Jeong (2013); Rakusa (2016); Sanchez-Marquez, Guillem, Vicens-Salort and Vivas (2020). Lean six sigma, DMAIC approach was used to address non-compliance in quality of customer's specification in a computer design service system. The DMAIC approach was used to define the problem, measure the extent of the problem, analyze the problem to identify the root cause, find solutions to reduce the effects of the problems and finally sustain the improvements made (Bazrkar et al., 2017; Rameni \& Banuelos, 2018). For successful implementation of six sigma, the understanding of barriers and motivations is pertinent (Hekmatpanah, Sadroddin, Shahbaz, Mokhtari \& Fadavinia, 2008). Six-sigma is targeted to achieve perfection in every single process of a production (Narula \& Grover, 2015). It means having less than 3.4 defects per million opportunities or a success rate of $99.99 \%$. In view of this, lean six-sigma is a method that permits organizations to review their existing status and guide in improvement decision via analysis of status (Erbiyik \& Saru, 2015). This study aimed at assessing the contributions of Lean six sigma to production process optimization in $\mathrm{AB}$ Paper company with the objectives of minimizing the process defects in term of manufacturing wastes and optimizing the efficiency of the production process.

\section{Methodology}

The methodology adopted in the study is case study. This method illustrates how lean six sigma (LSS) is used to evaluate the existing production process in a paper company in Nigeria based on productivity and manufacturing wastes. The study also presented lessons learnt and managerial implications of LSS implementation. The case study method was chosen because it offered flexibility in design and implication by allowing both quantitative and 
qualitative analyses, which are more sensitive to organization complexities phenomena (Krueger, Mellat, \& Adams 2014; Merriam \& Grenier, 2019; Sanchez-Marquez et al., 2020; Sunder \& Mahalingam, 2018). A case study method offers a means of investigating complex and critical functions of the value chain (Ingason \& Jónsdóttir, 2017; Vinodh, Kumar \& Vimal, 2014). Another advantage of the method is it helps to make direct observations, collect data in a natural setting and compar so as to rely on the derived data (Ingason \& Jónsdóttir, 2017; Sunder, Ganesh \& Marathe, 2019). In this study, a real-time problem of customers' dissatisfaction was considered. The gathered data were based on machine functionality (up time, down time and cycle time), material and labour flow at every process stage of the production line. The assessment and optimization of the production process of the company were based on Lean tools like Value Stream Mapping (VSM), Process Cycle Efficiency (PCE), Kanban, Poka-Yoke, 5S, Pareto chart and analysis. These tools are valuable for diagnosing and resolving set of organizational problems (Bazrkar et al., 2017; Sunder et al., 2019). Qi Macros application embeded in Microsoft Excel is used to design the value stream mapping for the process value chain. The overview of the lean tools is presented thus:

\title{
2.1. Value Stream Mapping (VSM)
}

It is a Lean Manufacturing tool suitable for the analysis and design of the flow of materials/ information that is required to deliver products to customers (Roother \& Shook, 2003). Also, it can assist in significant wastes reduction during production

\subsection{Process Cycle Efficiency (PCE)}

It is defined as the ratio of value-added time to total time of a process (Ying, 2011). This is expressed as equation 1

$$
P C E=\frac{V D T}{T T} \times 100 \%
$$

Where:

\author{
PCE is the Process Cycle Time (sec) \\ VDT is the Value-Added Time (sec) \\ TT is the Total Lead Time $=$ VDT + NVDT
}

\subsection{Takt Time}

This is defined as time required to produce a sellable unit quantity of product (Rajenthirakumar, Mohanram \& Harikarthik, 2011). This matches production against customer's demand. It is expressed as equation 2

$$
T=\frac{T_{a}}{T_{d}}
$$

Where;

$T$ is the Takt Time (work time between two or more consecutive time $\mathrm{t}$ ) (sec)

$T_{a}$ is the Net time available to work

$T_{d}$ is the Time demand (customer demand)

Note: net available time is the amount of time available for work to be done, which excludes the break time and other foreseen shutdown like scheduled maintenance, staff briefing and training.

\subsection{Kaizen}

This is a form of continuous improvement measure adopted by early Japanese companies which includes Kanban that can be termed as just-in-time (JIT) and POKA-YOKE 


\section{5. $5 \mathrm{~S}$}

This is a workplace standardization philosophy by Japanese companies with 5 different words starting with $\mathrm{S}$. These describe arrangement of workplace efficiency by identifying, sorting of items, maintaining the work area and sustaining the new order (David, 2010). The meaning of the 5 S is stated below:

1. Sorting: Examine and eliminate all unnecessary tools, parts, and instruction

2. Setting in order: Arrangement of tools and machine parts in such a way that the needed ones are easily seen

3. Sweep: Make the workplace clean of any form of hazardous materials or event that can contribute to hazard.

4. Standardizing: Let there be a standard or general work procedures for all kinds of jobs

5. Sustenance: find the best way of maintaining and reviewing standard.

\subsection{Pareto Chart and Analysis}

This is a statistical technique that determines which few actions or processes contributed to the majority of the outcomes (Shingo, 1989; David, 2010; Dash, 2020). The data analyzed is then translated into bars arranged in either ascending or descending order using excel software (Hart \& Hart, 1989).

\section{Case-Study Background}

This case study was undertaken in a paper production company managed as Private Limited Liability Company. The organization was established in 2015 as a printing and publishing company, located in the South-West province in Nigeria. The company is made up of five (5) functional Departments namely; Central Account, Production, Marketing, Logistics and Procurement with a total of seventy (70) staff. The production Department takes about $50 \%$ of the entire labour force of the organization. The company receive, process and make deliveries of orders on a daily basis, up to an average of fourteen thousand $(14,000)$ pieces/order. Figure 2 shows the value chain of the production line. Value chain gives idea that a production system comprises of other subsystems, each with input, transformation process and their respective output (Michael, 1985; Sayidmia, 2016). It is a systematic approach to examine the development of competitive advantage (Sayidmia, 2016). The stages that represent the value chain of $\mathrm{AB}$ production line are described below:

1. Concept Visualization: this is the conceptual design of the text and graphic, which involves strategic and creative work, as well as finalization of the idea and approval of the conceptual design.

2. Design/ Plate cutting: this involves the creation of the image and text in the real form on the plate using software.

3. Printing: this is the impression of the text and image from the plate to a paper in hard form.

4. Cutting /Trimming: this is the removal or dressing of the offset of the printed paper in preparation for folding.

5. Folding: this is the arrangement of the printed sheet pieces in pages.

6. Stitching/Gluing: this involves the bringing together of the printed sheet piece in pages. It can also be bond adhesive.

7. Finishing: this is the final stage of book development where the book is examined for any process error from the previous stages and preparation for delivery.

The case organization shows little or no compliance to lean manufacturing, thus providing opportunity for academia-Industry collaboration (Sunder \& Mahalingam, 2018). 


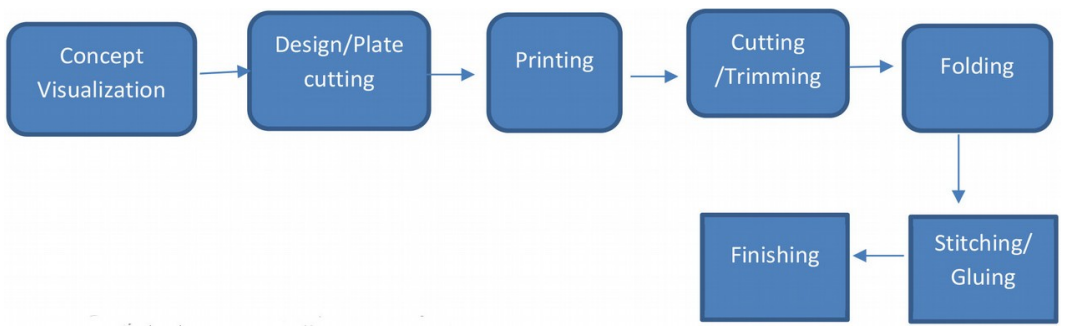

Figure 2. Value Chain of AB Production line

\subsection{Business Case}

In the bid to maintain a good customer-client relationship by the management of the organization, there is a need to improve on the production process efficiency, lead time and takt time. Also reduce the manufacturing wastes in terms of percentage down time, number of non-conforming products and degree of labour flow. The management decided to engage lean six sigma practitioners to evaluate the current production process of the company. The lean six sigma team comprise] a post-doctoral researcher that specialized on quality management and a senior lecturer in the University who is also a Black Belt certified. The team engaged in company's document review and one-on-one interview with some selected customers and staff from the production Department. These were further supported by self-observation on the production floor for a period of three months to understudy the production processes.

\section{Results}

This section presents the results of the lean six sigma assessment of the company before and after implementation of Lean six sigma tools.

\subsection{Present Value Stream Mapping of AB Production Line}

The existing Value Stream Mapping of $\mathrm{AB}$ production line is revealed from different activities which emanated from different stages of operations. The data necessary to develop the existing Value Stream Mapping were presented in Tables 1 and 2 with other important data like number of operators $(\mathrm{O})$, assistant operator $(\mathrm{AO})$, and staff (S) were presented. The estimation of the completion of the existing Value Stream Mapping involved the introduction of timeline at the tail end of the map, recording the value added and non-value-added time. Consideration was given to machine running operations.

The present Value Stream Mapping of $\mathrm{AB}$ production line shows the flow of order, raw materials, labour, information, Value-Added Time and Non-Value-Added Time. It aids in the computation of the required processes and their respective cycle time, up time, customer order and batch sizes. By examining the present Value Stream Mapping of the production line, the question of number of labour required at each unit, levels of value added time, non-value-added time and any improvement measure to be carried out should be asked as these would help to determine Process Cycle Efficiency, lead time and takt time. Figure 3 shows the present Value Stream Mapping of AB paper production line which was actually managed by three (3) representatives. Orders were received from customers for production to commence. As observed, there are so many Non-Value-Added Time reflected from each unit of the production line which are quantified in the form of up and down time. The implementation of lean tools and sixsigma are expected to improve on the Non-Value-Added Time while the total labour also cut down.

\begin{tabular}{|c|c|c|c|c|c|c|c|c|c|c|c|c|}
\hline Run & \multicolumn{3}{|c|}{ Design/ Plate Cutting } & \multicolumn{4}{|c|}{ Printing } & \multicolumn{3}{c|}{ Cutting/Trimming } & \multicolumn{3}{c|}{ Stitching/Gluing } \\
\hline & UT & CT & DT & UT & CT & DT & UT & CT & DT & UT & CT & DT \\
\hline 1 & 2250 & 2880 & 630 & 1764 & 2880 & 1116 & 3346 & 4680 & 1334 & 2064 & 2880 & 816 \\
\hline 2 & 1980 & 2880 & 900 & 1680 & 2880 & 1200 & 2880 & 4680 & 1800 & 1980 & 2880 & 900 \\
\hline
\end{tabular}

Note: CPT Machine speed: 750 rpm; Curd 64 and G70 Machine speed are 500 and 245 rpm respectively; Cutting machine speed: 100 pieces/min; 3,500 pieces/batch

Table 1. Existing Down Time, Cycle Time, and Up Time (All time in seconds) 


\begin{tabular}{|c|l|r|r|}
\hline S/N & \multicolumn{1}{|c|}{ Processing Stage } & Average VDT (Sec) & Average NVDT (Sec) \\
\hline 1 & Concept Visualization & 1000 & 25000 \\
\hline 2 & Design/Plate Cutting & 900 & 2500 \\
\hline 3 & Printing & 1780 & 350 \\
\hline 4 & Cutting/Trimming & 2400 & 720 \\
\hline 5 & Folding & 50 & 1300 \\
\hline 6 & Stitching/Gluing & 1500 & 1100 \\
\hline 7 & Finishing & 2500 & 2100 \\
\hline & Total & $10130(23.4 \%)$ & $33070(76.6 \%)$ \\
\hline
\end{tabular}

Table 2. Existing Value Added and Non-Value-Added Time of the production line

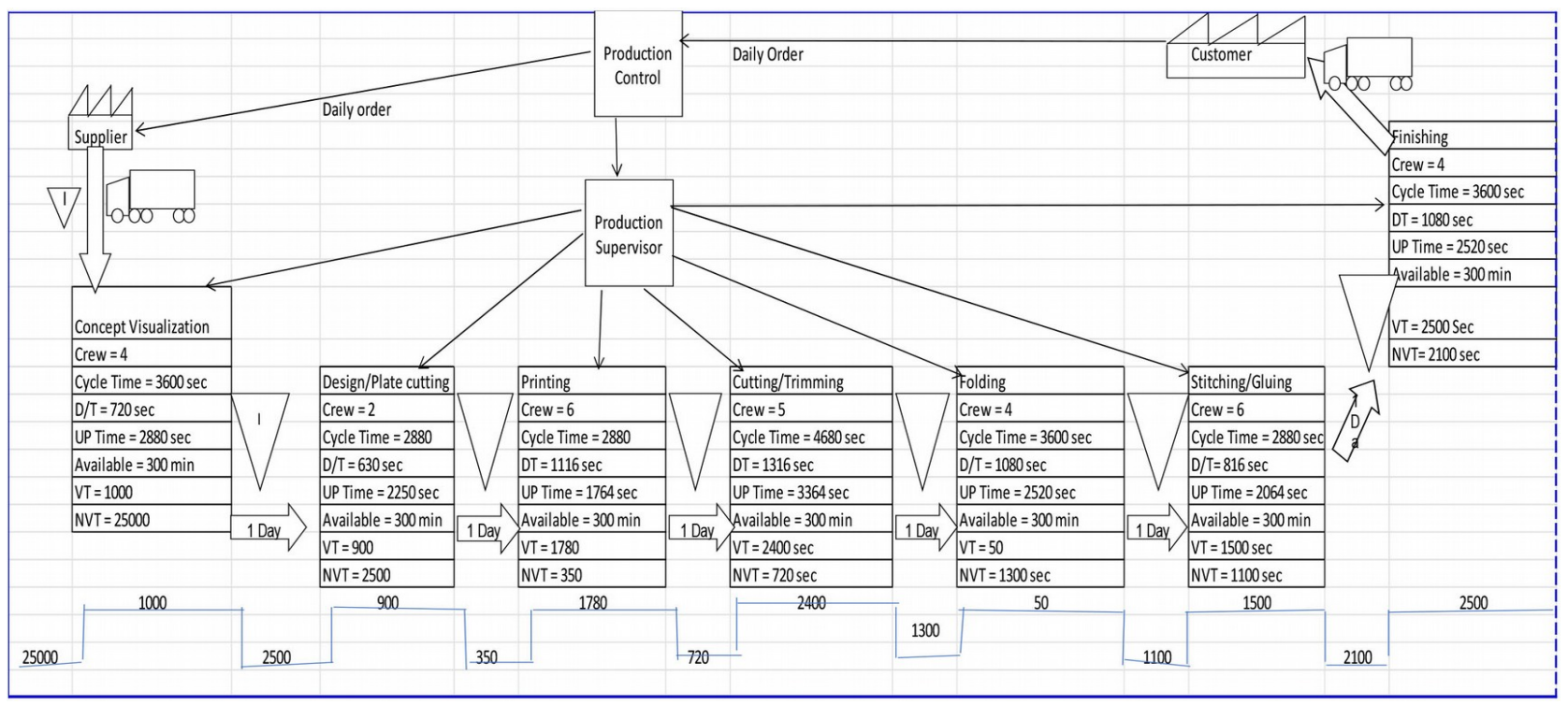

Figure 3. Present Value Stream Mapping of AB Production line

\subsection{Present Process Cycle Efficiency of AB Paper Production Line}

Value Added Time $=10130$ seconds

Non-Value-Added time $=33,070$

Present Lead Time $=$ Value Added Time + Non-Value-Added time

$$
=10130+33070=43200 \text { seconds }
$$

$$
\text { Process Cycle Efficiency }=\frac{\text { ValueAddedTime }}{\text { LeadTime }} \times 100 \%=23.4 \%
$$

From the above calculation, it is estimated that production cycle efficiency (PCE) is $23.4 \%$ which falls below benchmark of $25 \%$ (Ying, 2011), while the present lead time is very high.

\subsection{Present Takt Time of AB Paper Production Line}

The present takt time of the production line was calculated to be $4.11 \mathrm{sec} /$ piece i.e, production of salable unit of product takes $4.11 \mathrm{sec}$. This is presented in the Table 3 which is expected to increase by implementation of lean tool and six-sigma. 


\begin{tabular}{|c|l|c|}
\hline S/N & \multicolumn{1}{|c|}{ Description } & Time (min) \\
\hline 1 & Working shift/day & 2 shifts \\
\hline 2 & Hours/shift & 10 hours \\
\hline 3 & Available time/ shift & $600 \mathrm{~min}$ \\
\hline 4 & Set up time/shift & $30 \mathrm{~min}$ \\
\hline 5 & Lunch time/shift & $30 \mathrm{~min}$ \\
\hline 6 & Planned shut down time/shift & $60 \mathrm{~min}$ \\
\hline 7 & Net-working time $/$ shift & $480 \mathrm{~min}$ \\
\hline 8 & Net available time/day & $57600 \mathrm{~seconds}$ \\
\hline 9 & Customer demand/day & $14000 \mathrm{pieces} / \mathrm{day}$ \\
\hline & Takt Time & $4.11 \mathrm{sec} / \mathrm{piece}$ \\
\hline
\end{tabular}

Table 3. Present Takt time of AB Paper Production line

\subsection{Present Manufacturing Waste in the AB Production Line}

Three major wastes were observed in $\mathrm{AB}$ production line namely: non-conforming products, waste of time (down time) and undue motion of labour.

\subsubsection{Estimation of Non-Conforming Products}

The estimation of non-conforming products is presented in Table 4. The basis of the estimation is based on the conformity of the production six sigma standard. The consideration was given to machine running process stages.

\begin{tabular}{|c|c|c|c|c|c|c|c|}
\hline Process Stage & $\begin{array}{l}\text { Total } \\
\text { order } \\
\text { Pieces }\end{array}$ & $\begin{array}{l}\text { No piece/ } \\
\text { day }\end{array}$ & $\begin{array}{c}\text { No Pieces/ } \\
\text { batch }\end{array}$ & $\begin{array}{l}\text { Rejected } \\
\text { piece/ } \\
\text { batch }\end{array}$ & $\begin{array}{c}\text { Average } \\
\text { Rejection/ } \\
\text { day }\end{array}$ & $\begin{array}{l}\text { Rejection/Mi } \\
\text { llion } \\
\text { opportunities }\end{array}$ & $\begin{array}{c}\text { Gap at six } \\
\text { sigma Level } \\
x \leq 34,000 \leq 6^{5}\end{array}$ \\
\hline \multirow[t]{4}{*}{ Design/Plate cutting } & 380000 & 14000 & 3500 & 150 & 155 & 43400 & -9400 \\
\hline & & & & 160 & & & \\
\hline & & & & 140 & & & \\
\hline & & & & 170 & & & \\
\hline \multirow[t]{4}{*}{ Printing } & 380000 & 14000 & 3500 & 190 & 228 & 63840 & -29840 \\
\hline & & & & 250 & & & \\
\hline & & & & 230 & & & \\
\hline & & & & 240 & & & \\
\hline \multirow[t]{4}{*}{ Cutting/Trimming } & 380000 & 14000 & 3500 & 25 & 47 & 13160 & 20840 \\
\hline & & & & 50 & & & \\
\hline & & & & 72 & & & \\
\hline & & & & 40 & & & \\
\hline \multirow[t]{4}{*}{ Gluing/Stitching } & 380000 & 14000 & 3500 & 100 & 122 & 34160 & -160 \\
\hline & & & & 120 & & & \\
\hline & & & & 128 & & & \\
\hline & & & & 140 & & & \\
\hline
\end{tabular}

Table 4. Estimation of Non-Conforming Products

From Table 4, the total customers' orders were 380000 pieces for a given period in a month, which was reduced to 14000 pieces per day. Four batches in two shifts were taken per day to give 3500 pieces per batch. Data on non-conforming products per batch was collected for the machine processing stages. From the estimation of 
rejection per million opportunities, all production stages were non-compliant to six sigma standard except that of trimming/cutting stage. The production from the printing section shows the highest degree of non-compliance with gap of 29840 pieces per million while gluing/stitching section had the least degree of rejection with a sixsigma gap of just 160 pieces per million.

\subsubsection{Estimation of Percentage Down-Time in AB Production Line}

The estimation of present down time in $\mathrm{AB}$ production line is presented in Table 5 which revealed the total idle time in a given period of a month for the production of customers' orders. Consideration is also given to machine running process stages.

\begin{tabular}{|c|c|c|c|c|c|c|}
\hline Unit & $\begin{array}{c}\text { Causes of the Down } \\
\text { time }\end{array}$ & $\begin{array}{l}\text { Down } \\
\text { Time } \\
\text { (sec) }\end{array}$ & $\begin{array}{l}\text { Average } \\
\text { Down Time }\end{array}$ & $\begin{array}{l}\text { Cycle } \\
\text { Time } \\
\text { (sec) }\end{array}$ & $\begin{array}{l}\% \text { Down } \\
\text { Time }\end{array}$ & Machine \\
\hline \multirow{2}{*}{ Design/Plate Cutting } & Plate Damage & 630 & 765 & 2880 & 26.6 & Computer-To-Plate \\
\hline & Poor Impression on plate & 900 & & & & \\
\hline \multirow[t]{2}{*}{ Printing } & Plate Misalignment & 1116 & 1158 & 2880 & 40 & Curd 64/G70 \\
\hline & Ink Wetting & 1200 & & & & \\
\hline \multirow[t]{2}{*}{ Cutting/Trimming } & $\begin{array}{l}\text { Machine break down due } \\
\text { power source }\end{array}$ & 1334 & 1567 & 4680 & 33.5 & Minabmda \\
\hline & Job Misalignment & 1800 & & & & \\
\hline \multirow[t]{3}{*}{ Gluing / Stitching } & Skipped Stitches & 816 & 858 & 2880 & 30 & Polar-Motta 90 \\
\hline & Variable Stitch Density & 900 & & & & \\
\hline & Overall Down Time & & 4348 & 13320 & 32.64 & \\
\hline
\end{tabular}

Table 5. Estimation of Percentage Down-Time in AB Production line

The percentage down time in $\mathrm{AB}$ production line is $32.64 \%$. Which means about one-third of the production cycle time goes into idle time which also contributed to very low process cycle efficiency.

\subsubsection{Pareto Analysis of Down-Time in AB Production Line}

Figure 4 presents the Pareto Chart of the down time of $\mathrm{AB}$ production line. From Figure 4, it can be deduced that about $90 \%$ of the down time of the production line was as a result of ink wetting. Plate misalignment and job misalignment contributed between $80-90 \%$ of the down time, poor printing impression and variable stitch density also contributed about $70 \%$, machine breakdown due to power failure and skipped stitches contributed $60 \%$ to the down time, while about $50 \%$ of the down time was caused by plate damage.

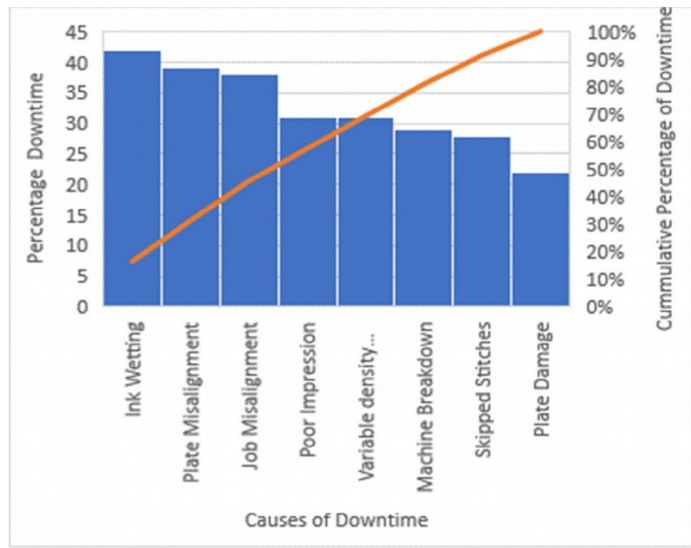

Figure 4. Pareto Chart of the Down Time of AB Production Line 


\subsubsection{Estimation of Present Labour in AB Production Line}

The data presented for present labour force in $\mathrm{AB}$ production line is shown in Table 6. According to lean manufacturing principle, over flowing of labour in the production line is termed as waste.

From table 6, the total labour in the production line is 33, where printing and stitching section has the highest number of work with staff strength of 6 .

\begin{tabular}{|c|l|c|c|c|}
\hline S/N & Production Stage & No of Operator (O) & No of Assistant Operator (AO) & No of Co-Worker (CW) \\
\hline 1 & Concept Visualization & 1 & 1 & 3 \\
\hline 2 & Design/ Plate cutting & 1 & 1 & 1 \\
\hline 3 & Printing & 1 & 1 & 4 \\
\hline 4 & Cutting/ Trimming & 1 & 1 & 3 \\
\hline 5 & Folding & 0 & 0 & 4 \\
\hline 6 & Gluing /Stitching & 1 & 1 & 4 \\
\hline 7 & Finishing & 0 & 0 & 23 \\
\hline & Total & 5 & 5 & 4 \\
\hline
\end{tabular}

Table 6. Present Labour of AB Production line

\subsection{Implementation of Lean Tools in AB Production Line}

There are some improvements points which differ by production stages in the present Value Stream mapping. Delay and sometimes insufficiency of raw materials were reported by the production supervisor thereby increasing the non-value-added time. Kaizen in terms of Kanban and POKA-YOKE as continuous improvement measures was recommended. At every stage of the production processes was $5 \mathrm{~S}$ recommended due to high level of non-value-added times observed due to poor standardization, lack of proper arrangement of tools and machine parts. Sorting and sweeping of the shop floor to eliminate all unnecessary tools and parts or hazardous materials were not properly done. The present value stream mapping of $\mathrm{AB}$ production line with improvement points is presented in the Figure 5.

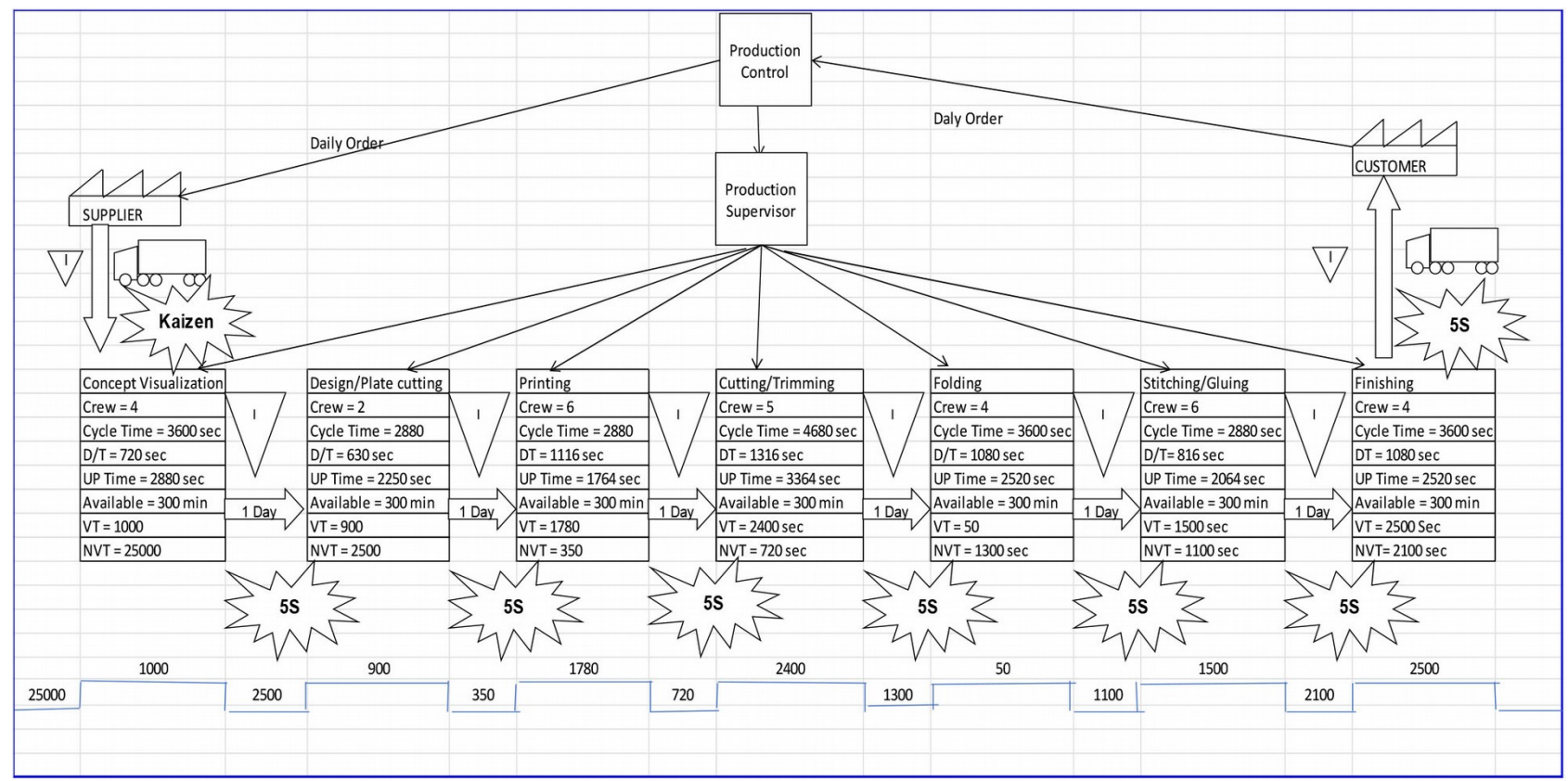

Figure 5. Present VSM of AB Production line with Improvement Point 


\subsection{Improved Value Stream Mapping of AB Production Line}

The future value stream mapping of $\mathrm{AB}$ production line, after careful observation and implementation of some lean appropriate tools reflected improvements in Value Added time and Non-Value-Added time. This is presented in Table 7.

From Table 7, there is a decrease in non-value-added time to approximately $60 \%$. Figure 6 shows improved value stream mapping of $\mathrm{AB}$ production line

\begin{tabular}{|c|l|r|r|r|}
\hline S/N & Processing Stage & Average VDT (Sec) & Average NVDT (Sec) & \% Reduction in NVDT \\
\hline 1 & Concept Visualization & 1000 & 12500 & 50 \\
\hline 2 & Design/Plate Cutting & 900 & 1250 & 50 \\
\hline 3 & Printing & 1780 & 175 & 50 \\
\hline 4 & Cutting/Trimming & 2400 & 144 & 80 \\
\hline 5 & Folding & 50 & 268 & 80 \\
\hline 6 & stitching/Gluing & 2500 & 220 & 80 \\
\hline 7 & Finishing & $10130(40.3 \%)$ & 428 & 80 \\
\hline & Total & $14985(59.7 \%)$ & \\
\hline
\end{tabular}

Table 7. Future Value Added and Non-Value-Added Time of the production line

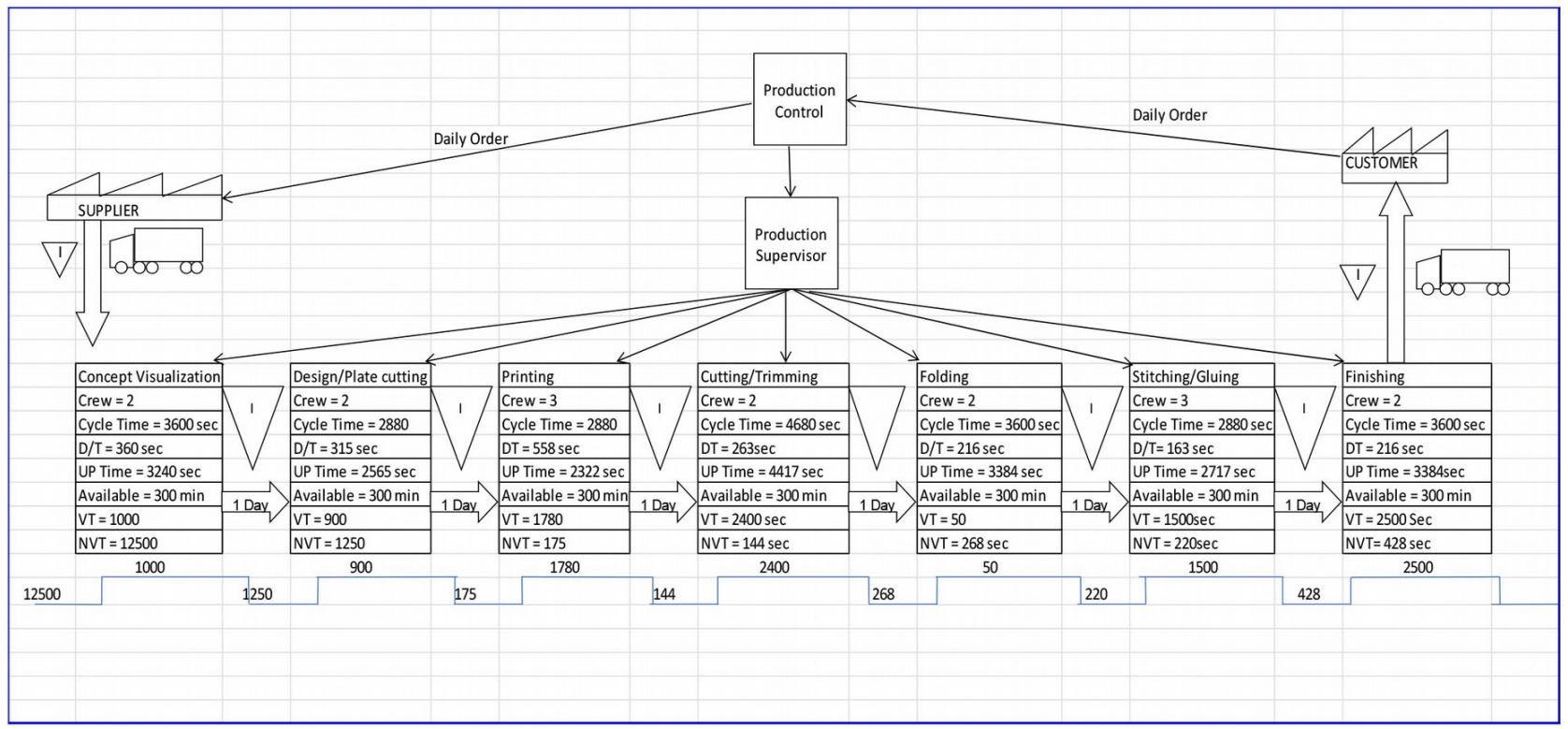

Figure 6. Improved Value Stream Mapping of AB Production Line

\subsection{Improved Process Cycle Efficiency (PCE) of AB Production Line}

The process cycle efficiency of $\mathrm{AB}$ production line after proper implementation of lean tools and six sigma methodologies is estimated to be approximately $40 \%$. This also impacted on the lead time to drastically reduce to 25115 seconds.

Value Added Time $=10130$ seconds

Non-Value-Added time $=14985$

Improved Lead Time $=$ Value Added Time + Non-Value-Added time 


$$
=10130+14985=25115 \text { seconds }
$$

$$
\text { Process Cycle Efficiency }=\frac{\text { ValueAddedTime }}{\text { LeadTime }} \times 100 \%=40 \%
$$

\subsection{Improved Takt time of AB Production Line}

The takt time of $\mathrm{AB}$ production line after the implementation of lean tools and six sigma approaches is seen to increase from 4.11 seconds/piece to 4.71 seconds/piece. Table 8 shows the improved takt time.

\begin{tabular}{|c|l|c|}
\hline S/N & Description & Time (min) \\
\hline 1 & Working shift/day & 2 shifts \\
\hline 2 & Hours/shift & 10 hours \\
\hline 3 & Available time/shift & $600 \mathrm{~min}$ \\
\hline 4 & Set up time/shift & $10 \mathrm{~min}$ \\
\hline 5 & Lunch time/shift & $10 \mathrm{~min}$ \\
\hline 6 & Planned shut down time/shift & $30 \mathrm{~min}$ \\
\hline 7 & Net-working time $/$ shift & $550 \mathrm{~min}$ \\
\hline 8 & Net available time/day & $66000 \mathrm{~seconds}$ \\
\hline 9 & Customer demand/day & $1,000 \mathrm{pieces} / \mathrm{day}$ \\
\hline & Takt Time & $4.71 \mathrm{sec} / \mathrm{piece}$ \\
\hline
\end{tabular}

Table 8. Improved Takt time of AB Production line

\subsection{Improved Manufacturing Wastes in the $A B$ Production Line}

The three (3) wastes that were observed in $\mathrm{AB}$ production line after implementation of lean tools and six sigma approaches were non-conforming products, down time and undue motion of labour.

\subsubsection{Improved Estimation of Non-Conforming Products}

The improved estimation of non-conforming products is presented in the Table 9 . The basis of the estimation is based on the conformity of the production to six sigma standards. The consideration was given to machine running process stages.

Observations from Table 9 showed that rejection piece per batch of non-conforming products have reduced to the barest minimum after the implementation of the lean tools and six sigma methodologies. The table showed that all the machine running processes now conformed to six sigma standard as their rejection per million opportunities are less than 340000 pieces.

\begin{tabular}{|l|r|r|r|r|r|r|r|}
\hline \multicolumn{1}{|c|}{$\begin{array}{c}\text { Process Stage } \\
\text { order } \\
\text { Pieces }\end{array}$} & $\begin{array}{c}\text { No piece/ } \\
\text { day }\end{array}$ & $\begin{array}{c}\text { No Pieces/ } \\
\text { batch }\end{array}$ & $\begin{array}{c}\text { Rejected } \\
\text { piece/ } \\
\text { batch }\end{array}$ & $\begin{array}{c}\text { Average } \\
\text { Rejection/ } \\
\text { day }\end{array}$ & $\begin{array}{c}\text { Rejection/ } \\
\text { Million } \\
\text { opportunities }\end{array}$ & $\begin{array}{c}\text { Gap at six } \\
\text { sigma Level } \\
\mathbf{x} \leq 34000 \leq 6^{\mathbf{5}}\end{array}$ \\
\hline Design/Plate cutting & 380000 & 14000 & 3500 & 70 & 75 & 21000 & 13000 \\
\hline & & & & 79 & & & \\
\hline & & & & 70 & & & \\
\hline Printing & 380000 & 14000 & 3500 & 92 & 113 & 31640 & 2360 \\
\hline
\end{tabular}




\begin{tabular}{|c|c|c|c|c|c|c|c|}
\hline Process Stage & $\begin{array}{l}\text { Total } \\
\text { order } \\
\text { Pieces }\end{array}$ & $\begin{array}{l}\text { No piece/ } \\
\text { day }\end{array}$ & $\begin{array}{c}\text { No Pieces/ } \\
\text { batch }\end{array}$ & $\begin{array}{l}\text { Rejected } \\
\text { piece/ } \\
\text { batch }\end{array}$ & $\begin{array}{l}\text { Average } \\
\text { Rejection/ } \\
\text { day }\end{array}$ & $\begin{array}{l}\text { Rejection/ } \\
\text { Million } \\
\text { opportunities }\end{array}$ & $\begin{array}{l}\text { Gap at six } \\
\text { sigma Level } \\
x \leq 34000 \leq 6^{\circ}\end{array}$ \\
\hline & & & & 125 & & & \\
\hline & & & & 116 & & & \\
\hline & & & & 118 & & & \\
\hline \multirow[t]{4}{*}{ Cutting/Trimming } & 380000 & 14000 & 3500 & 25 & 47 & 13160 & 20840 \\
\hline & & & & 50 & & & \\
\hline & & & & 72 & & & \\
\hline & & & & 40 & & & \\
\hline \multirow[t]{4}{*}{ Gluing/Stitching } & 380000 & 14000 & 3500 & 20 & 25 & 7000 & 27000 \\
\hline & & & & 24 & & & \\
\hline & & & & 26 & & & \\
\hline & & & & 28 & & & \\
\hline
\end{tabular}

Table 9. Improved Estimation of Non-Conforming Products

\subsubsection{Improved Estimation of Down Time in AB Production Line}

The improved estimation of down time is presented in the Table 10. The consideration was given to machine running process stages.

The percentage improvement in the down time in the production line is approximately $11 \%$.

\begin{tabular}{|c|c|c|c|c|c|c|}
\hline Unit & $\begin{array}{c}\text { Causes of the Down } \\
\text { time }\end{array}$ & $\begin{array}{l}\text { Down } \\
\text { Time } \\
\text { (Sec) }\end{array}$ & $\begin{array}{l}\text { Average } \\
\text { Down Time }\end{array}$ & $\begin{array}{l}\text { Cycle } \\
\text { Time } \\
\text { (sec) }\end{array}$ & $\begin{array}{l}\% \text { Down } \\
\text { Time }\end{array}$ & Machine \\
\hline \multirow[t]{2}{*}{ Design/Plate Cutting } & Plate Damage & 315 & 383 & 2880 & 13.3 & Computer-To-Plate \\
\hline & Poor Impression on plate & 450 & & & & \\
\hline \multirow[t]{2}{*}{ Printing } & Plate Misalignment & 558 & 579 & 2880 & 20 & Curd 64/G70 \\
\hline & Ink Wetting & 600 & & & & \\
\hline \multirow[t]{2}{*}{ Cutting/Trimming } & $\begin{array}{l}\text { Machine break down due } \\
\text { power source }\end{array}$ & 267 & 314 & 4680 & 6.7 & Minabmda \\
\hline & Job Misalignment & 360 & & & & \\
\hline \multirow[t]{3}{*}{ Gluing / Stitching } & Skipped Stitches & 163 & 172 & 2880 & 5.9 & Polar-Motta 90 \\
\hline & Variable Stitch Density & 180 & & & & \\
\hline & Overall Down Time & & 1448 & 13320 & $10.9 \%$ & \\
\hline
\end{tabular}

Table 10. Estimate of Improved Down Time in AB Production Line

\subsubsection{Improved Estimation of Labour in $A B$ Production line}

The data presented for improved labour force in $\mathrm{AB}$ production line is shown in Table 11. According to lean manufacturing principle, over flowing of labour in the production line is termed as waste (Sayidmia, 2016).

From Table 11, the total labour in the production line has reduced to 16 after the implementation of lean tools and six sigma methodologies. Printing and stitching section have the highest number of works with staff strength of 3 each. 
\begin{tabular}{l|l|l|l|l} 
S/N & Production Stage & No of Operator (O) & No of Assistant Operator (AO) & No of Co-Worker (CW)
\end{tabular}

\begin{tabular}{|c|c|c|c|c|}
\hline 1 & Concept Visualization & 1 & 1 & 0 \\
\hline 2 & Design/ Plate cutting & 1 & 1 & 0 \\
\hline 3 & Printing & 1 & 1 & 1 \\
\hline 4 & Cutting/ Trimming & 1 & 0 & 1 \\
\hline 5 & Folding & 0 & 0 & 2 \\
\hline 6 & Gluing / Stitching & 1 & 1 & 1 \\
\hline \multirow[t]{2}{*}{7} & Finishing & 0 & 0 & 2 \\
\hline & Total & 5 & 4 & 7 \\
\hline
\end{tabular}

Table 11. Improved Labour of AB Production line

\subsection{Gap Analysis between Present and Improved States}

The gap analysis of the present and improved states of the $\mathrm{AB}$ production line, after the implementation of lean tools and six sigma methodologies was carried out through brainstorming session by the LSS team. The root causes and effects analyses of the problems was done using Ishikawa Diagram as presented in Figure 7, so as to design improvements and subsequent controls (Gupta et al., 2018; Roriz et al., 2017; Sokovic, 2010). The causes were grouped into four main categories, namely: work organization, machine, method and man.

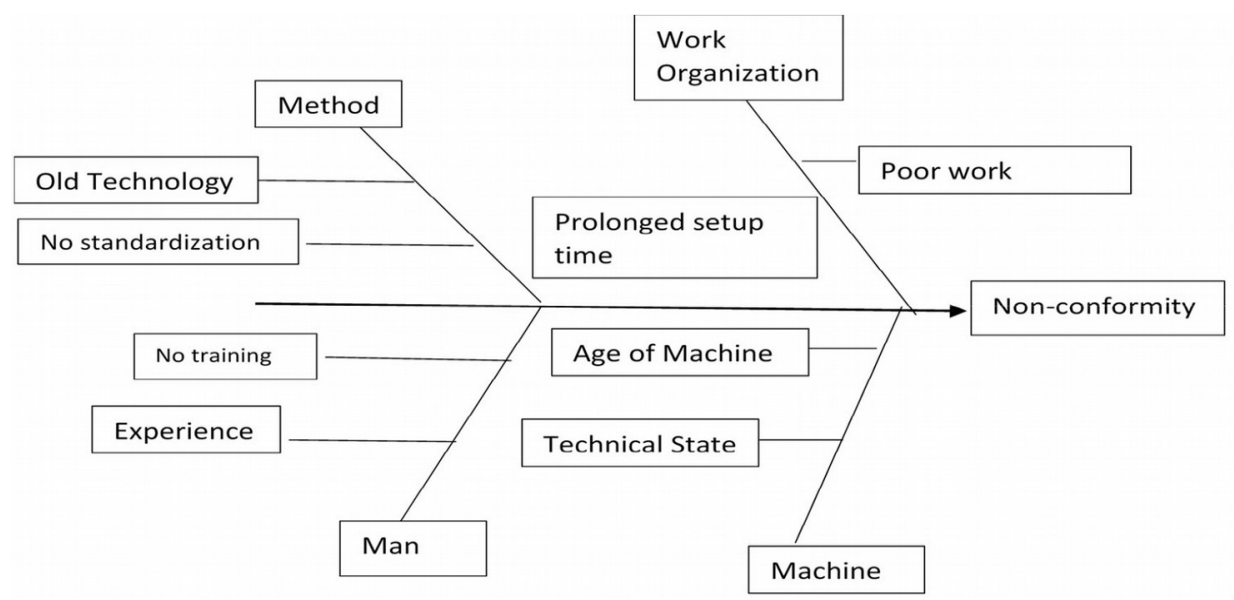

Figure 7. Root Causes and Effects Diagram of the Problems in AB production Line

\section{Results Discussion and Lessons Learnt}

The detailed analyses of the root causes of the problems, improvements strategies and lessons learnt were discussed in this section.

\subsection{Analysis on Process Cycle Efficiency (PCE)}

It is deduced from the results that PCE before implementation of lean six sigma (LSS) was $23 \%$, which improved to $40 \%$ after the implementation of LSS. This is linked to too many non-value-added time incurred most especially during non-machine running operations like concept visualization, design/plate cutting and finishing. The excess non-value-added time did prolong the production lead time which invariably impacted the PCE negatively below the minimum standard of $25 \%$. The problem of low PCE is traced to process method and work organization. It is observed that operators handling the processes used wrong methods due to less experience on the job. Also, insufficient implementation of control system was found in the organization. The poor control system resulted in attitudinal behavior of the operators. The improvement of PCE was achieved by implementation of kaizen (continuous improvement) on all the processes. It is systematic approach to improving efficiency and quality by gradual or incremental changes (Michael, 1985; Fled, 2000). The implementation of kaizen reduced unnecessary 
inventory, reduced production lead time and non-conforming products in the production floor. Also, implementation of kaizen involves intermittent training and re-training of the operators for skills and multi-skills on the job. Operators were made to understand the importance of team work. Another lean tool implemented to improve $\mathrm{PCE}$ in $\mathrm{AB}$ production line is work standardization. It is used to organize the production processes in such a way that they were being executed in the most effective way (Ahmed et al., 2018) by achieving accurate line balancing, minimizing undue work in process and serious reduction in non-value-added activities especially in the non-machine running processes (Belokar, Kumar, \& Khars, 2012). The strategic framework for Kaizen implementation is shown in Figure 8, which was basically designed for 5S implementation. It required good management vision which involved plan of constituting team.

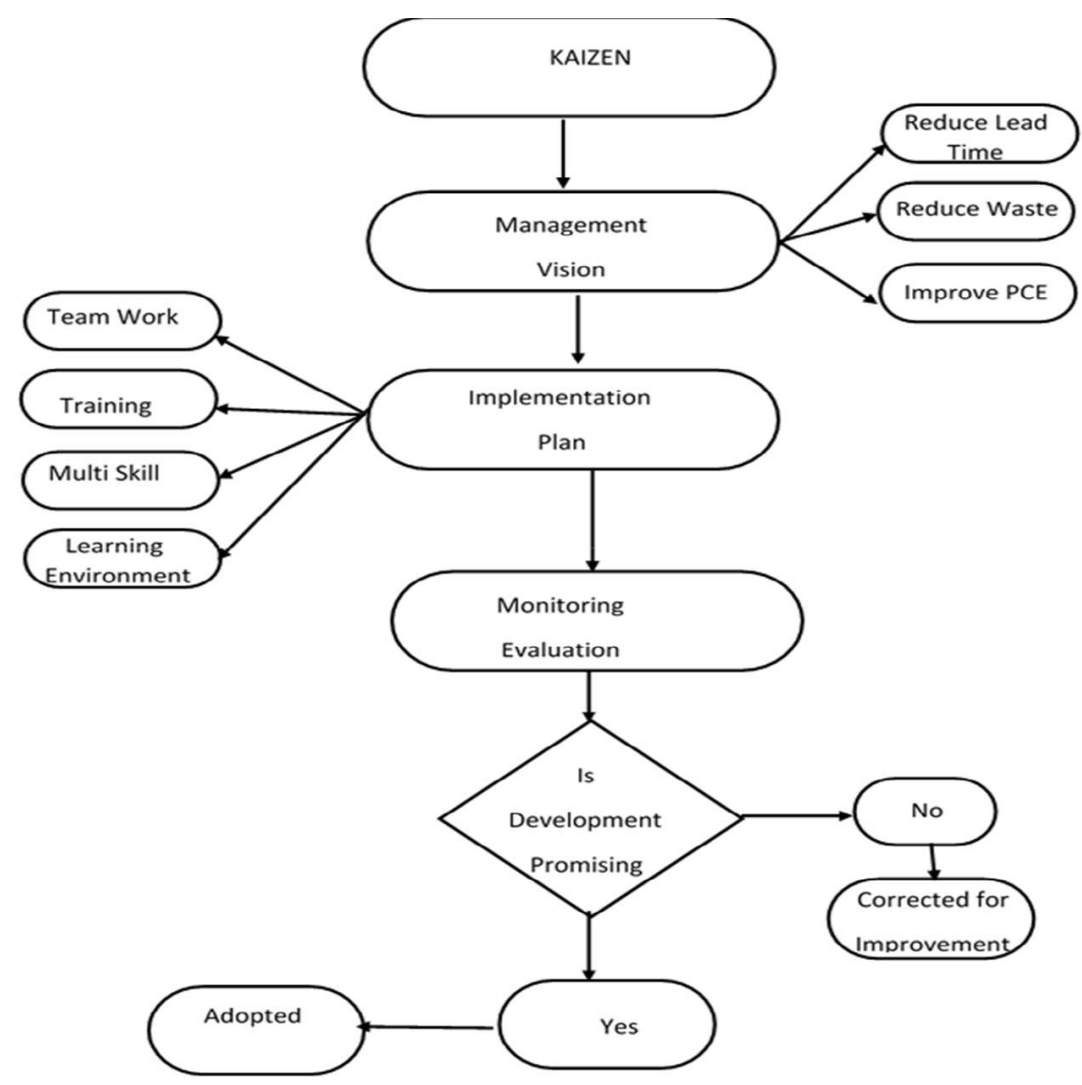

Figure 8. Strategic Framework for Kaizen Implementation

\subsection{Analysis on Takt Time}

Takt time as described by Rajenthirukumar et al. (2011) is the time required to produce a sellable unit quantity of the product, which is a function of net available time to work. Comparing table 3 and 8 , which show the estimations of takt time before and after implementation of LSS, it wasobserved that takt time before and after LSS was 4.11 and $4.71 \mathrm{sec} /$ piece, respectively. This shows more net available time to meet up with customers' demands after implementation of LSS. The problem of low takt time can be linked with three (3) factors of setup time/shift, lunch time/shift and planned shutdown time/shift especially on the machine running processes. These were all traceable to poor work organization as root cause. It was observed that the operators spent more time than necessary on these three factors, which constituted more non-value-added times and invariably impacted on the net available time to meet up with customers' demands. Low productivity of the operators especially with machine running processes is observed to be too much time allocated for planned shutdown and other factors. This is traceable to predisposition of the workers linked to motivation at work. This reflected on the number of produc piece per shift. The improvement on the takt time was achieved by implementation of LSS tools of Total Productive Maintenance (TPM), 5S and Single Minute Exchange of Die (SMED) (Bhadury, 2000; Sayidmia, 2016). The TPM was useful in minimizing setup time and planned shutdown time which were purposely designed for 
change-over of production order, corrective and preventive maintenance (Sayidmia, 2016). The lean tools and six sigma approaches encouraged maintenance by all operators involved with machines (Decentralized Maintenance). Its took care of the reliability of the equipment on the production floor (Sayidmia, 2016). Therefore, implementation of LSS reduced unnecessary down time of operation. Figure 9 show strategic framework to total productive maintenance which may involve training of operators and staff, decentralization of duties and other components of total productive maintenance must be implemented at all stages of production, most especially machine running processes. There should be monitoring and evaluation team on ground to ensure proper implementation and also giving feedback.

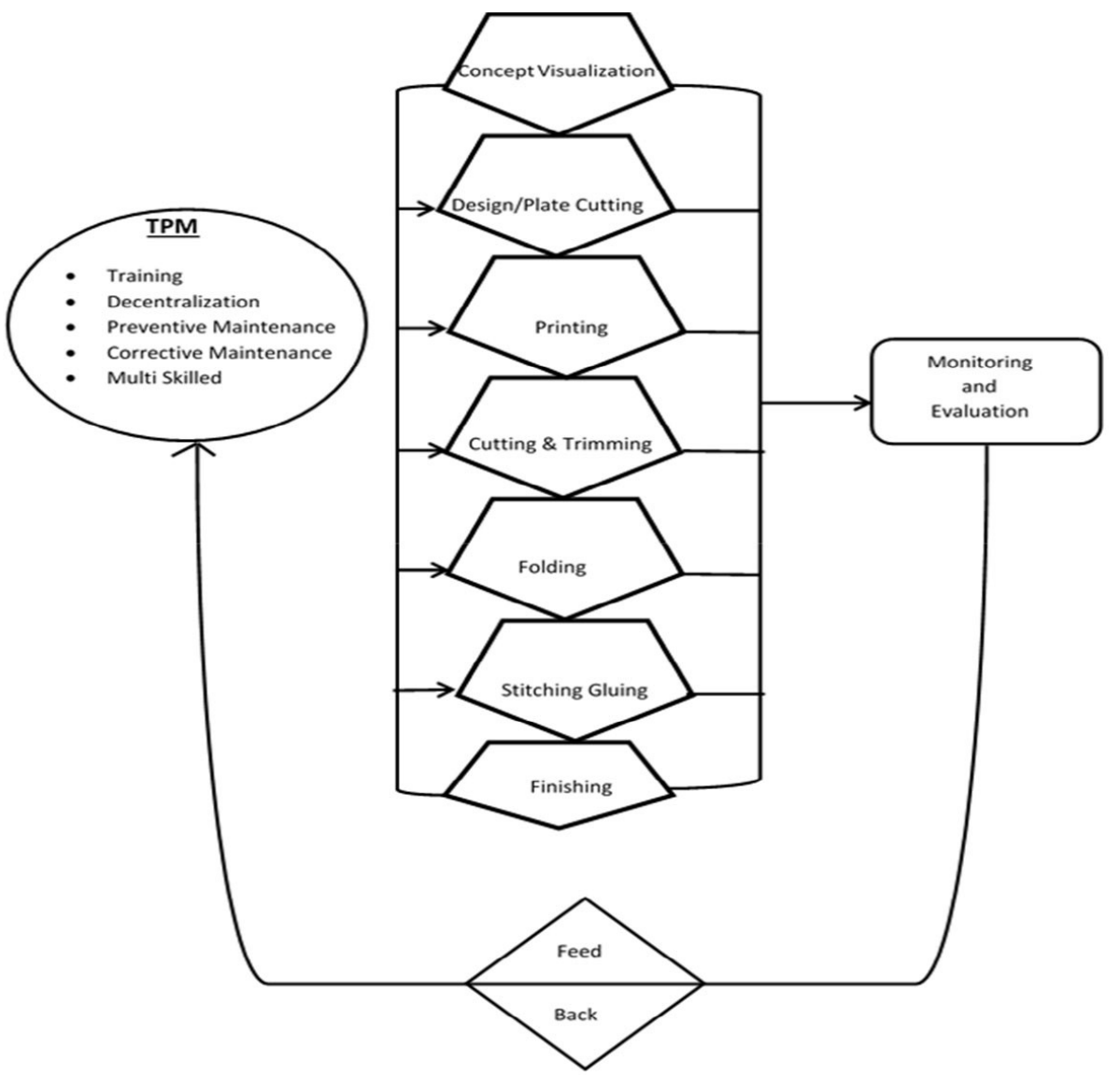

Figure 9. Strategic Framework for Total Productive Maintenance for AB production Line

\subsection{Analysis of Manufacturing Wastes}

The three major production wastes to be discussed are: non-conforming products, percentage downtime and over flowing labour as presented in Tables 4, 5 and 6, respectively. The improvements in the manufacturing wastes after implementation of LSS is presented in Tables 9, 10 and 11, respectively. Comparing Tables 4 and 9, it was observed that high quantity of non-conforming products existed before implementation of LSS in all the machine running operations with printing section having the most defected pieces. Also, percentage down time before and after implementing LSS were estimated as 32.64\% and $11 \%$, respectively as presented in Tables 5 and 10 in which printing section contributed the highest percentage down time. The third category of manufacturing waste was the overflowing labour which was estimated at 33 and 16 for before and after LSS, respectively. The major sources of the problems of manufacturing wastes in the production line emanated from the printing section and it can be linked to machine, man, method and work organization as the root causes. The technical state or depreciation levels of the machines were diagnosed. This caused generation of defected pieces and incessant breakdown of the machines, adding to frequency of down time and prolonged production cycle time, especially for G70 machine. Lack of standard procedure or clear instruction and manual guide on the usage 
of the machines for operators majorly affected G70 machine. Deficiency in the technical know-how of the operators of Curd 64 machine contributed to the frequency of defective pieces as it required specialized skills. Operators needed to be guided on how to choose formats of orders to make processes much more effective. No special training for operators except some verbal obligatory safety advice. The improvement on the manufacturing wastes was achieved by implementation of LSS approaches of TPM, kaizen, standardization of work, inventory management, $5 \mathrm{~S}$ and six sigma methodology of DMAIC. TPM is a suitable approach for the improvement problem because it's a man-machine based problem in production. TPM is a holistic approach to maintenance that involves three components namely; preventive, corrective and maintenance prevention (Sayidmia, 2016; Abdulmalek, Rajgopal \& Needy, 2006). This actually take care of the unnecessary down time and prolonged shutdown of machines. Kaizen, 5S (sort, setting, sweep, standardize and sustenance) implementation take care of high rate of defective products. Work standardization and inventory management monitor and control the inventory of staff to curtail over staffing.

\section{Conclusion and Implications}

This article has contributed towards the implementation of lean methodology in process industry. Application of LSS in this case has been able to solve real-time problems of productivity and manufacturing wastes which have direct implications on customers' satisfaction. It has also presented some theoretical and empirical implications by establishing a lean frame work for process industries when it has to do with improvement of real-time lean problems as listed:

1. Challenge of poor process cycle efficiency or productivity is improved from 23 to $40 \%$ by implementation of Kaizen and work standardization.

2. Challenge of manufacturing wastes is solved by improving on quantities of non-conforming products to conform to six sigma standard, reduced the level of down time from 32.6 to $11 \%$, and over staffing from 33 to 16 thereby saving cost on labour inventory by implementation of total productive maintenance (TPM), work standardization, inventory management and six sigma methodologies like 5S, DMAIC and DMADV.

3. The application of LSS in the presented case-study is an indication that it can be successfully adapted to other process metrics like quality, responsiveness, total turnaround time and so on.

4. Involvement of an expert with black Belt certified alongside with University Faculty resource and quality management students was a leverage during the execution of the project. In view of this, academic-industry collaboration is encouraged.

\subsection{Limitations}

1. This article has practically and in no doubt contributed to the body of knowledge in the field of LSS with focus to manufacturing sector. Nevertheless, it presents a single case organization which may not be substantial for generalization.

2. The lesson learnt and implications presented can still be further validated using some lean based simulation software.

\section{Declaration of Conflicting Interests}

The authors declared no potential conflicts of interest with respect to the research, authorship, and/or publication of this article.

\section{Funding}

The authors received no financial support for the research, authorship, and/or publication of this article. 


\section{References}

Abdulmalek, F.A., Rajgopal, J., \& Needy, K.L. (2006). A Classification Scheme for the Process Industry to Guide the Implementation of Lean. Engineering Management Journal, 18(2), 15-25.

https://doi.org/10.1080/10429247.2006.11431690

Ahmed. S, Manaf, N.F., \& Islam, R. (2018). Measuring Lean Six Sigma and Quality Performance for Health care Organization. International Journal of Quality and Service Science, 10(3), 267-278. https://doi.org/10.1108/IJQSS-092017-0076

Anthony, P. (2018). Lean in a Lean Economy. Manufacturing Today [online]. Available at: http://www.manufacturing-today.com/sections/columns/2001-lean-in-a-lean-economy

Atradius Conduction Team (ACT) (2018). Global Economic Outlook 2017: No time for complacency. Atradius [online]. Available at: https://atradius.nl/documents/atradius economic research-economic outlook november 2017.pdf

Bazrkar, A., Iranzadeh, S., \& Farahmand, N.F. (2017). Total quality model for aligning organization strategy, improving performance, and improving customer satisfaction by using an approach based on combination of balanced scorecard and lean six sigma. Cogent Business \& Management, 4(1), 1390818.

https://doi.org/10.1080/23311975.2017.1390818

Beacham, W. (2018). Ten years on from the financial crisis. [online] Icis.com. Available at: https://www.icis.com/resources/news/2017/08/10/10132891/ten-years-on-from-the-financialcrisis/ [Accessed 12 Feb. 2018]

Belokar, R.M., Kumar, V., \& Khars, S.S. (2012). Application of Value Stream Mapping in Automobile: A Case Study. International Journal of Innovative Technology and Exploring Engineering, 1(2), 152-157.

Bhadury, B. (2000). Management of productivity through TPM. Productivity, 4(2), 240-251.

Bhuiyan, N., \& Baghel, A. (2005). An overview of continuous improvement: from the past to the present. Management Decision, 43(5), 761-71. https://doi.org/10.1108/00251740510597761

Chen, C., Lu, I., Wang, K., Jang, J., \& Dahlgaard, J.J. (2015). Development of quality management in Taiwan the past, present and future. Total Quality Management \& Business Excellence, 26(1/2), 3-13.

https://doi.org/10.1080/14783363.2014.981071

Chiarini, A. (2012). Risk management and cost reduction of cancer drugs using Lean Six Sigma tools, Leadership in Health Services. Total Quality Management \& Business Excellence, 25(4), 318-330. https://doi.org/10.1108/17511871211268982

Crawford, R. (2004). Ammunition enterprise excellence ready for tomorrow? USA Armor School Research Library.

David, L. (2010). Project Risk and Risk Management.

Dash, R. (2020). A two stage grading approach for feature selection and classification of microarray data using Pareto based feature ranking techniques: A case study. Journal of King Saud University-Computer and Information Sciences, 32(2), 232-247.

Edgeman, R.L. (2010). Lean Six Sigma in service: applications and case studies. Total Quality Management \& Business Excellence, 21(10), 1060-1061. https://doi.org/10.1080/14783360903491977

Erbiyik, H., \& Saru, M. (2015). Six Sigma implementations in supply chain: an application for an automotive subsidiary industry in Bursa in Turkey. Procedia - Social and Behavioral Sciences, 195, 2556-2565.

https://doi.org/10.1016/j.sbspro.2015.06.447

Eurostat (2017) Industrial production (volume) index overview. Available at: http://ec.europa.eu/eurostat/statistics

Fled, M.W. (2000). Lean Manufacturing: Tools. Techniques, and how to use them. Boca Raton, London: The St. Lucie Press. https://doi.org/10.1201/9781420025538 
Furterer, S., \& Elshennawy, A.K. (2011). Implementation of TQM and Lean Six Sigma tools in local government: A framework and a case study. Total Quality Management \& Business Excellence, 16(10), 1179-1191. https://doi.org/10.1080/14783360500236379

Gaither, N. (1994). Production and Operations Management (6th ed.). Orlando, New York: The Dryden Press.

Gupta, V., Jain, R., Meena, M.L., \& Dangayachi, G.S. (2018). Six-Sigma Application in Tire Manufacturing Company: A Case Study. Journal of Industrial Engineering International, 14, 511-520. https://doi.org/10.1007/s40092017-0234-6

Harrington, H.J. (1996). The complete benchmarking implementation guide: Total Benchmarking Management. New York: McGraw-Hill.

Hart, K.M., \& Hart, R.F. (1989). Quantitative methods for quality improvement. Milwaukee, WI: ASQC Quality Press. Santosh: Pre-Press.

Hekmatpanah, M., Sadroddin, M., Shahbaz, S., Mokhtari, F., \& Fadavinia, F. (2008). Six Sigma process and its impact on the organizational productivity. World Academy of Science, Engineering and Technology, 43, $2070-3740$.

Ingason, H.P., \& Jónsdóttir, E.R. (2017). The house of competence of the quality manager. Cogent Business \& Management, 4(1),1345050. https://doi.org/10.1080/23311975.2017.1345050

Krueger, D.C., Mellat, P.M., \& Adams, S. (2014). Six Sigma Implementation: A Qualitative Case Study Using Grounded Theory. Production Planning \& Control, 25(10), 873-889. https://doi.org/10.1080/09537287.2013.771414

Laureani, A., \& Antony, J. (2010). Reducing employees' turnover in transactional services: a Lean Six Sigma case study. International Journal of Productivity and Performance Management, 59(7), 688-700.

https://doi.org/10.1108/17410401011075666

Madsen, D.Q., Risvik, S., \& Stenheim, T. (2017). The diffusion of Lean in the Norwegian municipality sector: An exploratory survey. Cogent Business \& Management, 4(1), 1411067. https://doi.org/10.1080/23311975.2017.1411067

Merriam, S.B., \& Grenier, R.S. (2019). Qualitative Research in Practice: Examples for Discussion and Analysis. Hoboken, NJ: Jossey-Bass.

Meza, D., \& Jeong, K.Y. (2013). Measuring efficiency of Lean Six Sigma project implementation using data envelopment analysis at NASA. Journal of Industrial Engineering and Management, 6(2), 401-422.

https://doi.org/10.3926/jiem.582

Michel, E.P. (1985). Competitive Advantage: Creating and Sustaining Superior Performance (1, 3-52). New York: Free Press.

Moser, P., Isaksson, O., \& Seifert, R. (2017). How process industries can improve supply chain performance. CSCMP Supply Chain Quarterly: Strategy.

Mwacharo, F.K. (2013). Challenges of Lean Management - Investigating the challenges and developing a recommendation for implementing Lean management techniques. Bachelor. HAMK University of Applied Sciences.

Narula, V., \& Grover, S. (2015). Six Sigma: literature Review and Implications for future research. International Journal of Industrial Engineering \& Production Research, 26(1),13-26.

Pearn, W.L., \& Chen, K.S. (1999). Making decisions in assessing process capability index C-pk. Quality and Reliability Engineering International, 15(4), 321-326. https://doi.org/10.1002/(SICI)1099-1638(199907/08)15:4<321::AIDQRE258>3.0.CO;2-5

Rajenthirakumar, D., Mohanram, P.V., \& Harikarthik, S.G. (2011). Process Cycle Efficiency Improvement through Lean: A Case Study. International Journal of Lean Thinking, 2(1).

Rakusa, S. (2016). Business Process Improvement using Lean Six Sigma: A example of Improving the Onboard Process. Master Dissertation. University of Ljubijani. 
Rameni, A., \& Banuelos, R. (2018). DMAIC Approach to Address Non-Compliances in 3D Features Based Computer Generated Design Model. Proceeding of International Conference of Industrial Engineering and Operation Management. Pretoria South Africa.

Roriz, C., Nunes, E., \& Sousa, S. (2017). Application of Lean Production Principles and Tools for Quality Improvement of Production Process in a Cartoon Company. Procedia Manufacturing, 11, 1069-1076. https://doi.org/10.1016/j.promfg.2017.07.218

Rother, M., \& Shook, J. (2003). Learning to see: value-stream mapping to create value.

Saidul Huq, K.M. (2018). Impact of Lean Manufacturing on Process Industries. Master of Business Administration Dissertation. Bucking Institute of Technology, Sweden.

Sanchez-Marquez, R., Guillem, J.M.A., Vicens-Salort, E., \& Vivas, J.J. (2020). A systemic methodology for the reduction of complexity of the balanced scorecard in the manufacturing environment. Cogent Business \& Management, 7(1), 1720944. https://doi.org/10.1080/23311975.2020.1720944

Sayidmia, M.D. (2016). An approach to reduce Manufacturing waste and Improve the Process Cycle Efficiency of a footware Industry by using Lean Six-Sigma Model. Master of Science in Management of Technology Dissertation. Institute of Appropriate Technology. Bangladesh University of Engineering and Technology.

Shingo, S. (1989). A Study of the Toyota Production System from an Industrial Engineering Viewpoint. Productivity Press.

Sunder M.V., \& Mahalingam, S. (2018). An Empirical Investigation of Implementing Lean Six Sigma in Higher Education Institutions. International Journal of Quality \& Reliability Management, 35(10), 2157-2180. https://doi.org/10.1108/IJQRM-05-2017-0098

Sunder M.V., Ganesh, L.S., \& Marathe, R.R. (2019). Lean Six Sigma in Consumer Banking: An Empirical Inquiry. International Journal of Quality \& Reliability Management. https://doi.org/10.1108/IJQRM-01-2019-0012

Sokovic, M.D., Pavletic, K., \& Pipan, K. (2010). Quality improvement methodologies: PDCA cycle, RADAR matrix, DMAIC and DFSS. Journal Achievements in Materials and Manufacturing Engineering, 43(1), 476-483.

Vinodh, S., Kumar, S.V., \& Vimal, K.E.K. (2014). Implementing Lean Sigma in an Indian Rotary Switches Manufacturing Organization. Production Planning \& Control, 25(4), 288-302.

https://doi.org/10.1080/09537287.2012.684726

Wu, C.C, Kuo, H.L, \& Chen, K.S. (2004). Implementing process capability indices for a complete product. The International Journal of Advanced Manufacturing Technology, 24(11), 891-898. https://doi.org/10.1007/s00170-003-1812-x

Ying, Z. (2011). Food safety and lean Six Sigma Model. University of Central Missouri. https://doi.org/10.5772/17288

Journal of Industrial Engineering and Management, 2021 (www.jiem.org)

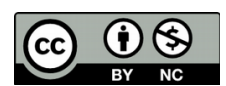

Article's contents are provided on an Attribution-Non Commercial 4.0 Creative commons International License. Readers are allowed to copy, distribute and communicate article's contents, provided the author's and Journal of Industrial Engineering and Management's names are included. It must not be used for commercial purposes. To see the complete license contents, please visit https://creativecommons.org/licenses/by-nc/4.0/. 